\section{A HISTORY OF}

\section{CHRISTIANITY IN}

THE BALKANS

By Matthew Spinka, $\$ 2.00$

First work in English showing the spread of Byzantine culture among the Slavs, by a noted authority in this field, opening up to many readers an entirely new and fruitful section of church history.

\section{TWO ELIZABETHAN PURITAN DIARIES}

By M. M. Knappen, $\$ 2.00$

Two hitherto unpublished diaries of Elizabethan Puritan divinesRichard Rogers and Samuel Ward -carefully edited and prefaced with an introductory study dealing with the chief traits of Puritan character in relation to the diaries themselves.

\section{BIBLIOGRAPHY OF}

THE CONTINENTAL

\section{REFORMATION}

\section{By Roland H. Bainton, $\$ 1.00$}

An indispensable book in this field, particularly for the reader who would rely primarily on English sources.

\section{RIVAL PRESUPPOSITIONS}

\section{IN THE WRITING OF}

\section{CHURCH HISTORY}

By W. W. Rockwell, $\$ .60$

A penetrating study of the educational bias underlying the writing of Church History.

\section{EPISCOPAL}

APPOINTMENTS

IN THE REIGN

\section{OF EDWARD II}

By W. E. L. Smith, $\$ 1.50$

An exhaustive study based almost entirely upon original material, and filling a need which has not been met hitherto by any other work.

\section{AMERICAN CONTACTS WITH THE EASTERN CHURCHES 1820-1870}

By P. E. Shaw, $\$ 2.00$

A history of the Greek Mission of the Protestant Episcopal Church, the Episcopal Mission to Constantinople, the work of the A. B. C. F. M. in Turkey and Greece and a history of the indigenous Greek Evangelical Church by an author well-qualified to write on the subject. Most timely in view of the present interest in ecumenical Christianity.

\section{CONGREGATIONALISM IN THE DUTCH NETHERLANDS}

By Raymond P. Stearns, $\$ 2.00$

The author presents hitherto unpublished documents relating to the English Congregationalists in Holland. New light on the history of Congregationalism.

These prices are only on direct orders from

THE AMERICAN SOCIETY OF CHURCH HISTORY 5757 UNIVERSITY AVENUE, CHICAGO, ILLINOIS 